\title{
Przypływ który nie unosi żadnej lodzi. Unia Europejska wobec rozwoju transnarodowej ekonomii krymigracyjnej
}

\section{Uwagi wprowadzające}

Od 2011 roku zarówno wewnątrz Unii Europejskiej, jak również na zewnątrz jej granic, powszechną uwagę wzbudza tzw. „kryzys migracyjny”. Percepcja tej kwestii, uznawanej za test solidarności, którego Europa jak dotąd nie zdała, daleko wykracza poza „tradycyjną” charakterystykę opartą na analizie regularnych ruchów migracyjnych. Zazwyczaj thumaczy się ich zachodzenie za pomocą licznych i rozbudowanych teorii stawiających sobie za cel eksplanację zachowań jednostek oraz grup przemieszczających się na określony obszar. Znaczące miejsce zajmuje wśród nich grupa teorii ekonomicznych ${ }^{1}$, biorących za podstawę siedem „praw migracji” sformułowanych w drugiej połowie XIX wieku przez Ernesta George'a Ravensteina (1885)². W odniesieniu do „volkerwanderung” na terytorium Unii Europejskiej z państw Afryki Północnej i Bliskiego Wschodu (Middle East and North Africa - MENA) standardowe teorie ekonomiczne są eksplanacyjnie zawodne. Na ich ograniczoną przydatność wpływa ułomność metodologiczna i jednowymiarowość warunkowana przyjęciem jako podstawy neoklasycznego modelu wypychania-przyciagania. Model ten, w kontekście zespołu zjawisk wpływających na zwiększenie się atrakcyjności UE dla migrantów jako obszaru docelowego, takich jak: 1) przeciagająca się wojna domowa w Syrii; 2) niestabilność wywołana przez „arabską wiosnę” (Przybylska-Maszner, 2011; Rewizorski, 2012; Fiedler, Osiewicz, 2015); 3) dezintegracja państwa libijskiego (Cyrenajka,

${ }^{1}$ Ekonomiczne teorie migracji zachodzą na trzech poziomach analizy: mikro, mezo i makro. Na poziomie mikro (teoria klasyczna i neoklasyczna) przyczyn migracji można się doszukiwać w obrębie wyznawanych przez jednostkę wartości, obieranych przez nią celów i wyrażanych oczekiwań (jednostka jako homo oeconomicus maksymalizujący zysk). Analiza na poziomie mezo, koncentruje się z kolei na gospodarstwie domowym jako wspólnocie dążącej nie tyle do maksymalizacji zysku, ile do minimalizacji ryzyka, a przez to do zapewnienia większej stabilności w zakresie dochodu, zatrudnienia, więzi społecznych. Cele gospodarstwa domowego można zilustrować za pomocą nowej ekonomicznej teorii migracji (NETM), będącej modyfikacją teorii klasycznej i neoklasycznej. Z kolei na poziomie makro migracja jest traktowana jako część większego obrazu - rozwoju gospodarczego. Za najbardziej reprezentatywną na tym poziomie uznaje się teorię dualnego rynku pracy (por. Lee, 1966, s. 47-57; Stark, Bloom, 1985; Okólski, 2006; Piore, 1979).

${ }^{2}$ Ernest George Ravenstein był brytyjskim kartografem i urzędnikiem zatrudnionym w ministerstwie wojny znanym jako autor przełomowego, w zakresie badań nad migracjami, eseju The Laws of Migration (1885). W kontekście eseju wspomnianego autora warto też przywołać nowsze prace poświęcone zarówno samemu Ravensteinowi, jak również interesującej go problematyce zmian ludnościowych w Walii i Anglii w drugiej połowie XIX wieku (por. Tobler, 1995, s. 327-343; Lawton, 1968, s. 55-74). 
Trypolitania, Fezzan); 4) wycofanie międzynarodowych wojsk z Afganistanu i rebelie w państwach Afryki Subsaharyjskiej, jest mało użyteczny. Jednocześnie nasilanie się nieregularnych migracji ${ }^{3}$, jest uznawane przez europejskich decydentów za kluczowy problem polityczny. Zasadniczy wpływ na jego percepcję przez establishment polityczny ma nacisk opinii publicznej postrzegającej migrantów z Afryki Północnej i Bliskiego Wschodu za poważne zagrożenie. Świadczą o tym liczne badania opinii publicznej, w tym także te, które dokonywane były przed erupcją ,kryzysu migracyjnego". Według The Transatlantic Trends: Immigration 2010, w którym prześledzono opinie respondentów z ośmiu państw (Francja, Hiszpania, Holandia, Kanada, Niemcy, Włochy, Stany Zjednoczone, Wielka Brytania), w państwach europejskich nielegalną/nieregularną migrację uznano za jeden z najpoważniejszych problemów. W wyżej wskazanym badaniu ok. 33\% Brytyjczyków wyraziło przekonanie, że napływ migrantów sprzyja zwiększeniu wskaźnika przestępczości. Podobnego zdania było $46 \%$ badanych Niemców i 56\% Włochów (GMFUS, 2011). Podobne wyniki przyniosły badania przeprowadzone w 2009 roku przez Komisję Europejską. Ponad 30\% pytanych Europejczyków uznało migrację za jeden z trzech najważniejszych problemów, z którymi musi zmierzyć się Unia Europejska (EC, 2009).

Pomimo niemal powszechnego przeświadczenia o wadze problemu migracyjnego, w UE jak dotąd nie udało się osiągnąc konsensusu w zakresie wypracowania wspólnego podejścia do migracji, zwłaszcza nieregularnej. Nie służyły temu dane, zgodnie z którymi nieregularne migracje na obszar UE-15 w ubiegłej dekadzie wpisywały się w trend spadkowy. Został on potwierdzony m.in. w analizach prowadzonych przez wyspecjalizowane komórki agencji Frontex (Frontex Risk Analysis Network - FRAN). Ewentualne, ,punktowe” wzmożenie napływu nieregularnych migrantów na obszar Schengen thumaczono lokalną dostępnością miejsc pracy przeznaczonych dla nisko wykwalifikowanych pracowników. Generalną (i dość uspokajająca opinię publiczna) tendencję spadkową oraz „punktowe” wzmaganie się dynamiki przepływów migracyjnych stanowiące wyjątek od reguły, wyrażał jeden z istotniejszych raportów Frontexu z 2009 roku. Stwierdzono w nim: „Obecnie spadający trend migracji nielegalnej generuje rodzaj przerwy czy odroczenia odnośnie do migracji nieautoryzowanych, który zakończy się, kiedy popyt na pracę w państwach członkowskich zacznie rosnąć" (Frontex, 2009). W raporcie tym zwrócono uwagę, że wyraźny i stały spadek migracji nieregularnej może być częścią wyłaniającej się prawidłowości, zgodnie z którą nieregularne migracje do UE wzrosną wraz z pojawieniem się prosperity w państwach UE-15 (a zatem szerszego rdzenia UE, ukształtowanego w latach 1957-1986).

${ }^{3}$ Wyróżnia się osiem przypadków, w których osoba niebędąca obywatelem państwa wchodzącego w skład UE jest uznawana za nieregularnego migranta: 1) w przypadku nielegalnego przekroczenia granicy; 2) przekroczenia granicy z użyciem nieprawdziwych dokumentów; 3) przekroczenia granicy z użyciem legalnych dokumentów, lecz zawierających nieprawdziwe informacje; 4) nieuprawnionego przekroczenia terminu pobytu zawartego w wizie turystycznej lub prawie do pobytu czasowego; 5) utraty statusu rezydenta; 6) bycia urodzonym jako syn/córka nieregularnych migrantów; 7) oddalenia się w czasie trwania procedury azylowej lub nieopuszczenia państwa goszczącego po uzyskaniu negatywnej decyzji azylowej; 8) nieskutecznego wykonania przez państwo docelowe migranta decyzji o wydaleniu go z powodów prawnych lub praktycznych (por. Worbs, 2005, s. 5-6; Clandestino Project, 2009). 
Powyższy pogląd, w świetle wydarzeń w państwach MENA zapoczątkowanych przez ,arabską wiosnę”, wydaje się zbyt uproszczony i jednowymiarowy. Relokacja ludności z obszaru Bliskiego Wschodu i Afryki Północnej do Europy, doprowadziła do głębokiego kryzysu migracyjnego i to w sytuacji, w której trudno jest stawiać tezę, iż państwa UE (szczególnie strefy euro) pokonały kryzys finansowy i weszły na ścieżkę szybkiego wzrostu gospodarczego, z czym skorelowane jest skokowe zapotrzebowanie na nieregularnych migrantów jako taniej siły roboczej. Kilka lat od publikacji wspomnianego raportu Frontexu z 2009 roku Europa stoi w obliczu masowego napływu migrantów, przybierającego postać tragedii humanitarnej. W odniesieniu jedynie do azylantów - w październiku 2015 roku w państwach UE rozpatrywano około 995 tysięcy wniosków azylowych, a zatem dwukrotnie więcej niż w tym samym okresie 2014 roku. Wzrost aplikacji najwyraźniej zaznaczył się w Niemczech, Węgrzech i Szwecji. O ile Węgry stały się obiektem zainteresowania ze względu na położenie geograficzne, o tyle Niemcy i Szwecja zostały przez migrantów wyobrażone jako paradise venues ze względu na wysoki oczekiwany tam standard życia oraz występowanie dobrze zorganizowanych sieci etnicznych, odgrywających niepoślednią rolę w wyborze miejsca docelowego (Aiyar i in., 2009, s. 6). O skali problemu świadczy fakt, że napływ uchodźców do UE w 2015 r., mierzony liczbą aplikacji azylowych przekroczył wielkości osiagane w okresie bezpośrednio następującym po upadku muru berlińskiego i wojnie w byłej Jugosławii (z wyjątkiem 1996 roku, kiedy to liczba uchodźców zmuszonych do przemieszczenia się w związku z działaniami wojennymi wyniosła ok. 1,4 mln). Według szacunków Międzynarodowego Funduszu Walutowego i Wysokiego Komisarza Narodów Zjednoczonych do Spraw Uchodźców (ang. United Nations High Commissioner for Refugees - UNHCR), w samej tylko Syrii w wyniku działań wojennych dyslokacji uległo $8 \mathrm{mln}$ osób, dodatkowo cztery miliony Syryjczyków szukało schronienia w państwach sąsiadujących (Aiyar i in., 2009, s. 7). Na migracje przemożny wpływ wywierają konflikty w Iraku, Afganistanie, państwach Afryki i Bałkanów. Przyjmuje się, że od stycznia do października 2015 roku Syryjczycy i obywatele państw bałkańskich stanowili odpowiednio 25\% i 15\% spośród wszystkich poszukujących azylu na terytorium państw UE. Duży udział w tej grupie mieli też Afgańczycy (13\%), Irakijczycy (9\%) i Pakistańczycy (4\%). Rezultatem masowej dyslokacji ludności z państw MENA stało się: 1) wyłonienie grupy „,państw przesiadkowych” na szlaku migracyjnym, takich jak Turcja, Grecja, Włochy; 2) pojawienie się w tych państwach ogromnych problemów ekonomicznych związanych z utrzymaniem uchodźców oraz zmianą struktury na ich rynkach pracy4; 3) dynamiczny rozwój grup przestępczych

${ }^{4}$ MFW szacuje, że od początku wojny w Syrii do połowy 2015 roku w Turcji schronienie znalazło ok. 2 mln uchodźców. Utrzymanie ich kosztowało ok. 8 mld USD, a zatem ok. 1\% PKB Turcji (liczonego w cenach rynkowych), określonego przez Bank Światowy w 2014 r. na poziomie 794,4 mld USD. Pod koniec 2014 roku ok. 83\% uchodźców z Syrii przeniosło się na obszary zlokalizowane w pobliżu granicy turecko-syryjskiej (ok. 62\%) oraz na obszary przylegające do Stambułu (21\%). Towarzyszyła temu reforma przeprowadzona przez rząd turecki w 2014 roku. Zagwarantowano w niej udzielenie czasowej ochrony uchodźcom, jednak nie wprowadzono mechanizmów zapewniających im dostęp do legalnego zatrudnienia na lokalnym rynku pracy. W rezultacie uchodźcy zasilili sektor nieformalny (nie poddającą się regulacjom państwa, nie opodatkowaną działalność gospodarczą). Tym samym zajęli oni miejsce okupowane wcześniej przez pracowników najniżej wykwalifikowanych oraz kobiety (zwłaszcza w rolnictwie). Lepiej płatne prace stały się niemal wy- 
charakteryzujących się hierarchiczną struktura, zdolnych do prowadzenia szeroko zakrojonej działalności pozwalającej im czerpać zyski z przemytu migrantów na obszar Europy; 4) wykształcenie się specyficznej, znajdującej się poza sferą obowiązującego prawa, choć zwykle tolerowaną przez lokalne władze, ekonomii migracyjnej (którą ze względu na napędzanie jej przez działalność zorganizowanych grup przestępczych oraz godzenie się migrantów na korzystanie z ich usług, nazywam „krymigracyjną"). Rozwijaniem ekonomii krymigracyjnej zainteresowane są zarówno przedsiębiorcze jednostki (np. taksówkarze, mali przedsiębiorcy) jak również silnie rozwinięte, transnarodowe grupy przestępcze, korzystające z rozległych powiązań politycznych i gospodarczych. Cechami wyróżniającymi transnarodową ekonomię krymigracyjną jest także: 1) istnienie specyficznych więzów między klientem (migrant) a usługodawcą (przemytnik); 2) funkcjonowanie ,przestępczej przestrzeni rynkowej", na której dokonuje się transakcji; 3 ) specjalizację zorganizowanych (posiadających określoną strukturę), silnie usieciowionych grup, trudniących się przemytem migrantów do Europy.

W niniejszym artykule, śledząc relacje między „eksplozją” nieregularnych migracji do Europy a rozpowszechnianiem się i wzrostem znaczenia sieci przestępczych, często o transnarodowym charakterze, dąży się do odpowiedzi na pytania: 1) kto migruje z obszaru MENA do Europy; 2) jakimi szlakami; 3) jaka jest rola sieci przemytniczych w najnowszej odsłonie volkerwanderung; 4) jakie są relacje między przemytnikami a migrantami; 5) czym charakteryzuje się struktura grup przemytniczych; 6) w jaki sposób reaguje na „kryzys migracyjny” UE? W niniejszym tekście wykorzystuje się założenia podejścia transnarodowego, zwanego też ,transnarodowością” lub „transnacjonalizmem”. Zwykle służy ono wyjaśnianiu istoty i form interakcji zachodzących pomiędzy dużymi grupami społecznymi, takimi jak partie polityczne, związki zawodowe, ruchy społeczne, grupy zawodowe itp., które podjęły aktywność w środowisku międzynarodowym, rozwijając z poziomu narodowego sieci działające ponad strukturami państwowymi (Witkowska, 2013; Rumford, 2003). W przypadku tego artykułu mowa o transnarodowych grupach przestępczych, które odpowiadają za stronę podażową ekonomii krymigracyjnej. Wskazane wyżej podejście teoretyczne, jest uzupełniane materiałem statystycznym i informacjami uzyskiwanymi z wywiadów z migrantami. Punktem wyjścia jest założenie, że transnarodowa ekonomia krymigracyjna (TEK) napędzana jest przez pozaprawną aktywność aktorów prywatnych (strona podażowa) oraz przez potencjalnych migrantów, którzy zgłaszają zapotrzebowanie na tego rodzaju usługi, często nie zdając sobie w pełni sprawy z konsekwencji wejścia w relacje kontraktualne z grupami przemytników (strona popytowa). Zakłada się także, że dynamiczne funkcjonowanie transnarodowej ekonomii krymigracyjnej jest jedną z głównych przyczyn nasilania się nieregularnych migracji oraz „kryzysu migracyjnego” w Unii Europejskiej. Ze względu na ograniczenia niniejszego artykułu analiza zostanie osadzona głównie w problematyce nieregularnych migracji z Afryki Północnej (zwłaszcza wybrzeży Libii) do UE.

łącznym udziałem rodzimej siły roboczej (por. http://data.worldbank.org/country/turkey; Del Carpio, Wagner, 2015; Swaminathan, 1991). 


\section{Przemyt migrantów - próba charakterystyki}

Analizując związek między nasilaniem się nieregularnych migracji do Europy a rozpowszechnianiem się i wzrostem znaczenia sieci przestępczych zajmujących się przemytem ludzi, warto za punkt wyjścia obrać szereg ustaleń, które pozwolą śledzić przedmiotową problematykę w określonych ramach pojęciowych, metodologicznych i teoretycznych. Zadanie jest o tyle utrudnione, że w literaturze wskazuje się, że ,przemyt migrantów” może przybierać wiele form organizacyjnych, konotowanych z użyciem rozmaitych określeń. Są one zwykle niedookreślone, tworzone ad hoc. Dominują próby zobrazowania kontraktualnych relacji między przemytnikiem (strona podażowa) i migrantem (strona popytowa) jako ,przemysłu przemytniczego”, „handlu migrantami”, ,rodzinnego interesu” (mom and pop smugglers), a także „zorganizowanej przestępczości” (Heckmann, 2004). W środowisku naukowym nie ma zgody odnośnie do sposobu ukazania wystandaryzowanego obrazu struktury grup przemytniczych. Część badaczy (Salt, Stein, 1997) wskazuje, że przemysł przemytniczy jest zdominowany przez hierarchicznie zdominowane transnarodowe grupy przestępcze, które: 1) wykorzystują istniejące od dawna szlaki przerzutowe; 2) wykazują dużą elastyczność przy dostosowywaniu modus operandi do wymogów otoczenia oraz charakterystyki przewożonego towaru (narkotyki, broń, migranci itd.). Inni zwracają uwagę na podział rynku między duże sieciowe organizacje przestępcze a lokalne sieci przemytnicze, oparte na więzach rodzinnych, przyjacielskich, etnicznych (Neske, 2006). Istnieje wreszcie pogląd, iż w odniesieniu do przemytu migrantów analizowanie tego procederu jako formy działalności przestępczości zorganizowanej (organized crime), powinno być zastąpione przez tzw. model przedsiębiorstwa. Zwolennicy tej argumentacji przekonują, że elastyczne i łatwo adoptujące się do zmiennych warunków „przedsiębiorstwa przestępcze” (criminal enterprises) mogą łatwo rozszerzać zakres działania i radzić sobie z nadzwyczajnymi sytuacjami. Przemytnicy, określani przez Passas i Nelken mianem ,przedsiębiorców” są zdaniem tych badaczy zorganizowani w zakresie koniecznym i wystarczającym do efektywnego prowadzenia nielegalnej działalności (Passas, Nelken, 1993, s. 223-243).

W niniejszym artykule przyjmuje się za podstawę dalszych rozważań eklektyczny model oparty na stanowisku pierwszym (przemysł przemytniczy jako domena transnarodowych grup przestępczych) i drugim (przemyt migrantów jako „biznes rodzinny”). Za przyjęciem takiego założenia przemawia rozpowszechniony w literaturze oraz w wywiadach z migrantami i przemytnikami pogląd wskazujący na istnienie trzech poziomów, na których prowadzony jest proceder przemytu migrantów.

Na pierwszym z nich przemyt migrantów ma charakter ograniczony. Uzależniony jest od aktywności energicznych i przedsiębiorczych jednostek. Ewentualna działalność w formie zorganizowanej jest na tym poziomie zawężona ze względu na liczbę zaangażowanych osób w proceder przemytu. Zwykle działania sygnalne w tym względzie podejmują członkowie rodzin lub znajomi potencjalnych migrantów, którzy udzielają im pomocy w zakresie przedostania się do obszaru docelowego. Nawet na tak niskim poziomie organizacyjnym uwidocznia się aktywność transnarodowych sieci migracji nieregularnej. Potencjalni migranci wykorzystują znajomych lub krewnych w UE, którzy wysyłają im zaproszenia. W przypadku braku możliwości legalnego 
przyjazdu, migranci korzystają z usług przemytników. Nielegalni migranci, dzięki początkowemu wsparciu transnarodowych sieci, przenikają na obszar państwa docelowego, zasilając w nim zwykle sektor nieformalny (Staring, 2004).

Na drugim poziomie dominują stosunkowo niewielkie grupy przestępcze. Wiedza na ich temat jest dość ograniczona. Grupy te, pomimo słabo rozbudowanej struktury są często wykorzystywane przez migrantów. Ci ostatni zwykle korzystają z więcej niż jednego przemytnika/grupy przemytniczej. Basak Bilecen (Bilecen, 2009) podejmując problematykę sieci przemytu ludzi z Bliskiego Wschodu (zwłaszcza Afganistanu, Iraku, Iranu) do UE, wskazuje w jednym z wywiadów z Irakijczykiem przemyconym do Amsterdamu na sposób wyszukiwania przez klienta (potencjalnego migranta) odpowiedniego ,usługodawcy” (przemytnika): „Poszedłem do cofee shopu, wiesz, w Turcji mamy çaycı i znalazłem kogoś, wiesz? [...] Kogoś kto chce zarobić trochę pieniędzy w tym biznesie. To nie jest trudne jeśli chcesz ich znaleźć, oni są wszędzie, nawet tutaj. Jeśli chcesz ich znaleźć to jest do zrobienia" (Bilecen, 2009, s. 11).

$\mathrm{Na}$ trzecim poziomie proceder przemytu migrantów prowadzony jest przez transnarodową przestępczość zorganizowaną (transnational organizad crime - TOC). Zgodnie z opracowaniami Biura Narodów Zjednoczonych ds. Narkotyków i Przestępczości (United Nations Office on Drugs and Crime - UNODC) przemyt migrantów obok handlu ludźmi, prania brudnych pieniędzy, nielegalnego handlu bronią, nielegalnego obrotu towarami, kradzieży własności intelektualnej i cyberprzestępstw, można określić jako główne formy aktywności TOC (UNODC, 2010; UNODC, 2011). Wspomniana instytucja wskazuje, że roczna wartość operacji TOC na świecie osiaga poziom ok. 870 mld USD, a zatem jest sześciokrotnie wyższa od środków oferowanych w ramach oficjalnej pomocy rozwojowej w skali globalnej. Istotny udział w zyskach zorganizowanych grup przestępczych zapewnia przemyt migrantów. W wielu przypadkach dochodzi przy tym do skrajnego łamania ich praw. Migranci są przez „usługodawców" bici, okradani, gwałceni, przetrzymywani w charakterze zakładników, za których uwolnienie ustanawia się określoną cenę (okup), narażani na śmierć w czasie niebezpiecznej podróży do punktu docelowego (utopienie w przypadku zatonięcia przepełnionej łodzi, odwodnienie w przypadku transportu przez rozległe tereny pustynne, uduszenie w kontenerach). Szacuje się, że przemyt migrantów z Afryki do Europy przekracza wartość ok. $100 \mathrm{mln}$ USD rocznie (UNDOC, 2010). Po stronie migrantów transport wiąże się z ogromnym ryzykiem. Międzynarodowa Organizacja do Spraw Migracji (International Organization for Migration - IOM) szacuje, że od stycznia do września 2014 r. przynajmniej 4077 migrantów zmarło w trakcie przemytu za granicę. Jest to liczba o $70 \%$ wyższa niż liczba zanotowanych przypadków śmierci migrantów dotyczących całego roku 2013. Dane te nie odzwierciedlają jednak faktycznej liczby ofiar, z powodu zaginięć oraz trudności w rejestrowaniu i potwierdzaniu przypadków śmiertelnych (ONZ, 2015).

Przemyt migrantów bywa rozpatrywany obok problemu handlu ludźmi jednakże są to procedery różniące się od siebie. Zgodnie z Protokołem przeciwko przemytowi migrantów droga ladowa, morska i powietrznq, uzupełniającym Konwencję Narodów Zjednoczonych przeciwko międzynarodowej przestępczości zorganizowanej, za „przemyt migrantów” uważa się „organizowanie, w celu uzyskania, bezpośrednio lub pośrednio, korzyści finansowej lub innej korzyści o charakterze materialnym, nie- 
legalnego wjazdu osoby na terytorium Państwa-Strony, którego taka osoba nie jest obywatelem lub w którym nie posiada stałego miejsca zamieszkania" (ONZ, 2000a, art. 3a)5. Z kolei „,handel ludźmi”, zdefiniowany w Protokole o zapobieganiu, zwalczaniu oraz karaniu za handel ludźmi, w szczególności kobietami i dziećmi z 2000 roku (tzw. Protokół z Palermo), oznacza: „werbowanie, transport, przekazywanie, przechowywanie lub przyjmowanie osób z zastosowaniem gróźb lub użyciem siły lub też z wykorzystaniem innej formy przymusu, uprowadzenia, oszustwa, wprowadzenia w błąd, nadużycia władzy lub wykorzystania słabości, wręczenia lub przyjęcia płatności lub korzyści dla uzyskania zgody osoby mającej kontrolę nad inną osobą, w celu wykorzystania. Wykorzystanie obejmuje, jako minimum, wykorzystanie prostytucji innych osób lub inne formy wykorzystania seksualnego, pracę lub usługi o charakterze przymusowym, niewolnictwo lub praktyki podobne do niewolnictwa, zniewolenie albo usunięcie organów" (ONZ, 2000b, art. 3a). Oba protokoły uzupełniają Konwencję Narodów Zjednoczonych przeciwko międzynarodowej przestępczości zorganizowanej, która w artykule 2 wskazuje na podmioty międzynarodowej przestępczości zorganizowanej (zorganizowane grupy przestępcze) ${ }^{6}$.

Pomimo widocznego rozgraniczenia definicyjnego na ,przemyt migrantów” $i$, ,handel ludźmi", pojęcia te bywają używane zamiennie, zwłaszcza w publikacjach z początku ubiegłej dekady (por. Salt, 2000). To uproszczenie wciąż pojawia się w obiegu

${ }^{5}$ Niniejszy protokół stanowiący część międzynarodowych regulacji dotyczących przemytu migrantów w znacznej mierze jest rezultatem zabiegów Austrii. W 1997 roku rząd tego państwa zaproponował wypracowanie nowego instrumentu prawnego w celu radzenia sobie z problemem przemytu migrantów. Propozycja zakładała zarówno penalizację tego procederu, jak również wskazanie środków do wykorzystania na etapie czynności dochodzeniowych, oskarżycielskich, ekstradycyjnych. Rząd austriacki uzasadniając nową regulację wskazywał na zagrożenie procederem przemytu migrantów dla społeczności międzynarodowej. Określił go mianem: „bardzo szczególnej formy transnarodowej przestępczości”, wymagającej szczególnej konwencji. Pomimo konkurencyjnej propozycji regulacyjnej, zgłoszonej przez Międzynarodową Organizację Morską (International Maritime Organization - IMO), Austria poparta przez Włochy aktywnie promowała nowy instrument prawny do walki z przemytem migrantów, osadzając go w szerszym kontekście działań podejmowanych przez Komisję Narodów Zjednoczonych ds. Zapobiegania Przestępczości i Wymiaru Sprawiedliwości (UN Commission on Crime Prevention and Criminal Justice) nakierowanych na zwalczanie transnarodowej przestępczości zorganizowanej. Realizacja celu rządu austriackiego przybliżyła się w 1998 r. Ustanowiono wówczas ad hoc komitet mający przygotować konwencję o zwalczaniu transnarodowej przestępczości zorganizowanej. Komitet ten uzyskał mandat do wypracowania międzynarodowego instrumentu prawnego pozwalającego na zwalczanie przemytu migrantów, w tym także drogą morską. W następstwie prac prowadzonych przez komitet, na mocy rezolucji A/RES/55/25 przyjętej 15 listopada 2000 r. na 55. Sesji Zgromadzenia Ogólnego ONZ, 112 państw podpisało Protokót przeciwko przemytowi migrantów drogq ladowa, morskq i powietrznq. Ten traktat międzynarodowy wszedł w życie 28 stycznia 2004 roku. Według stanu na 1 lipca 2016 roku, jego stronami są 142 państwa, w tym także państwa MENA, takie jak: Libia (od 24.09.2004 - data ratyfikacji), Egipt (1.03.2005), Syria (8.04.2009), Turcja (25.03.2003) (por. Gallagher, 2015, s. 190-191; UN, 1997; United Nation Treaty Collection, https://treaties.un.org/Pages/ViewDetails. aspx?src=TREATY\&mtdsg_no=XVIII-12-b\&chapter=18\&lang=en).

${ }^{6}$ Zgodnie $\mathrm{z}$ art. 2 Konwencji „Zorganizowana grupa przestępcza” oznacza posiadającą strukturę grupę składającą się z trzech lub więcej osób, istniejącą przez pewien czas oraz działającą w porozumieniu w celu popełnienia jednego lub więcej poważnych przestępstw określonych na podstawie niniejszej Konwencji, dla uzyskania, w sposób bezpośredni lub pośredni, korzyści finansowej lub innej korzyści materialnej (por. ONZ, 2000c). 
publicystycznym, mimo wysiłków wielu badaczy porównujących i wyjaśniających zakres znaczeniowy obu pojęć. Część środowiska naukowego argumentuje, że rozróżnienie nie ma znaczenia praktycznego, bowiem migranci, którzy dobrowolnie korzystają z usług przemytników, mogą znaleźć się w sytuacji przymuszenia do określonych działań/zaniechań. Tym samym ich status zmienia się z klientów organizacji przemytniczych na ofiary grup zajmujących się handlem ludźmi. Stawianie znaku równości między przemytem migrantów a handlem ludźmi zostało podkreślone m.in. w pracy Sary Webb i Johna Burowsa, opartej na wywiadach ze skazanymi przemytnikami i handlarzami ludźmi. W ocenie brytyjskich badaczy handel ludźmi i przemyt migrantów nakładają się na siebie. „Przestrzeń rynkowa” jest ukazana jako kontinuum między dwoma ekstremami, w ramach którego wielu początkowych klientów sieci przemytniczych staje się ofiarami handlarzy żywym towarem. To, że oba procedery są „,blisko siebie” w praktyce, tłumaczy dlaczego w literaturze dokonuje się ich wspólnej ekspozycji i analizy. Należy jednak zauważyć, że w nowszych publikacjach przemyt migrantów zaczęto ukazywać jako zjawisko, które wyłoniło się niedawno i nie jest tożsame z handlem ludźmi (Daniel, 2008; Zhang, 2007).

Istotnie, wydaje się, że możliwe jest nie tylko akademickie, ale także praktyczne rozróżnienie między przemytem migrantów a handlem ludźmi. Można je sprowadzić do trzech aspektów:

1) źródło zysku - podstawowym źródłem zysku i jednocześnie głównym motywem handlu ludźmi jest ich wykorzystywanie. Z kolei przemyt migrantów opiera swoją opłacalność na ułatwieniu nielegalnego przekroczenia granicy/dotarcia do miejsca docelowego przez daną osobę/grupę osób. Cechą charakterystyczną kontraktualnego związku między migrantem a przemytnikiem jest wygaśnięcie kontaktu między nimi po zrealizowaniu celu umowy ${ }^{7}$;

2) transnarodowość - przemyt migrantów zawsze odbywa się w wymiarze transnarodowym, tj. zorganizowana grupa przemytnicza dąży do przetransportowania danej osoby/osób i zapewnienia jej nielegalnego przemieszczenia się do miejsca docelowego (z państwa A do państwa B). W przypadku handlu ludźmi przemieszczenie danej osoby/grupy osób może zawierać element transnarodowy, lecz nie musi. Transport ofiar procederu handlarzy żywym towarem może zachodzić w obrębie danego państwa (tj. bez konieczności przekraczania granic państwowych). Co więcej handel ludźmi może dotyczyć osoby/grupy osób, w odniesieniu do których nie ma restrykcji wjazdowych do innych państw;

3) wiktymizacja - przemyt migrantów niekoniecznie wiąże się z naznaczeniem danej osoby jako ofiary przemocy. Zazwyczaj migranci godzą się na korzystanie z usług przemytników. Często jednak w trakcie transportu są zmuszani do uległości i oddania się przemytnikowi w sferze psychicznej, fizycznej i materialnej. W niektórych przypadkach migranci mogą wycofać swą zgodę na przemieszczenie się za pośred-

${ }^{7}$ Warto jednak zauważyć, że od tej reguły można znaleźć wyjątki wynikające z osobistych doświadczeń migrantów i przemytników. Serge Daniel rozmawiając w Paryżu z Afrykanami trudniącymi się pomocą w nielegalnym przekraczaniu granicy (passeurs) zaznaczył, że ,nielegalni migranci nigdy nie tracą całkowitego kontaktu z przemytnikami. To jest jak romans. Znane są przypadki, w których agenci podróży w Agadezie dekorują ściany swoich biur zdjęciami klientów, którym powiodło się w Europie" (Serge, 2008, s. 220; UNODC, 2011, s. 56). 
nictwem przemytników. Natomiast handel ludźmi zawsze wiąże się z wiktymizacja, a zatem jest poważnym przestępstwem ${ }^{8}$ wobec danej osoby. Ofiary procederu handlu ludźmi nigdy nie godzą się na uczestniczenie w nim. Zazwyczaj też stosuje się wobec nich różne formy zastraszania, kontroli, przemocy fizycznej i psychicznej.

Prezentując odmienne stanowisko od przedstawionego przez Webb i Burrowsa należy zauważyć, że rozróżnienie między przemytem migrantów a handlem ludźmi ma istotne znaczenie praktyczne. Osobom będącym ofiarami handlu żywym towarem oferuje się zwykle pomoc prawną i finansową. Empiryczne studia wskazują, że migranci znajdują się w znacznie gorszej sytuacji (Horwood, 2009). Wbrew zapisom Protokołu przeciwko przemytowi migrantów, zgodnie z którym każde państwo-strona ma obowiązek zagwarantowania i ochrony podstawowych praw osób których życie lub/i bezpieczeństwo zostało zagrożone w trakcie wspomnianego procederu, w niektórych państwach zatrzymany i skazany zostaje migrant, podczas gdy trudno uchwytny przemytnik korzysta ze swej bezkarności. Takie postępowanie z jednej strony sprawia, że migrant staje się metaofiarą (może zostać wykorzystany przez przemytnika oraz wydalony przez władze państwa jego pobytu). $Z$ drugiej strony jest wyrazem frustracji i bezradności służb państw, na których terytorium przedostają się nieregularni migranci.

\section{Transnarodowa ekonomia krymigracyjna i jej aktorzy}

Z dotychczasowych rozważań wynika, że problem przemytu migrantów do UE, w znacznej mierze jest ,„produktem” transnarodowej ekonomii krymigracyjnej. Jej siłę napędową stanowią usieciowione grupy przestępcze (strona podażowa), ale także sami migranci (strona popytowa), którzy decydując się na relokację z Afryki i Bliskiego Wschodu do Europy działają z zamiarem wynikowym, tj. przewidując niebezpieczeństwa związane z transportem do miejsca docelowego - godzą się na jego dokonanie. Kwestią dyskusyjną jest wszakże stopień przewidywania przez potencjalnych migrantów konsekwencji związanych z podjęciem decyzji o skorzystaniu z usług przemytników. W celu ukazania choćby uproszczonego obrazu TEK należy odpowiedzieć na pytania o to: 1) kto migruje; 2) które trasy najczęściej są wybierane przez migrantów i co jest tego przyczyna; 3) jaka jest specyfika działania transnarodowych grup przestępczych.

Szczególnie dużą grupą osób przemieszczających się do Europy za pośrednictwem przemytników są Syryjczycy. Od 2011 roku (tj. od początku wojny domowej) państwo to opuściły ponad cztery miliony osób. W okresie 2011-2014 uchodźcy syryjscy trafiali głównie do obozów w Turcji i Jordanii. Wraz z nasilaniem się konfliktu w Syrii, rozszerzaniem go na główne miasta takie jak Hims i Damaszek, niekorzystną dla milionowej diaspory syryjskiej polityką prowadzoną przez Liban, a także brakiem zdecydowanej reakcji na wojnę domową ze strony społeczności międzynarodowej, duża część uchodźców zdecydowała się na korzystanie z usług sieci przemytniczych. Operują one na dwóch szlakach: 1) centralnym szlaku śródziemnomorskim (głównie z Libii, rzadziej z Egiptu), który jest obecnie drugim największym kanałem migracji do UE.

${ }^{8}$ Wspomniana już Konwencja przeciwko międzynarodowej przestępczości zorganizowanej za „poważne przestępstwo” uznaje „zachowanie stanowiące przestępstwo podlegające maksymalnej karze pozbawienia wolności w wysokości co najmniej czterech lat, lub karze surowszej”. 
Migranci drogą morską docierają do Lampedusy, na Maltę lub na Sycylię. W 2015 r. do Włoch dotarło tą trasą ok. 150 tys. ludzi, głównie obywateli państw położonych w Afryce Zachodniej lub Rogu Afryki. Kolejnych 9 tys. przybyło w pierwszych dwóch miesiącach 2016 r. (Mindal, Sasnal, 2016); 2) wschodnim szlaku śródziemnomorskim (szlaku egejskim) - najczęściej wybieranym przez Syryjczyków. Łączy on wybrzeże tureckie (zwłaszcza miasta takie jak Izmir i Bodrum uważane za punkty zborne migrantów) z greckimi wysepkami Lesbos, Kos i Samos.

Obok Syryjczyków wśród migrantów korzystających z centralnego szlaku śródziemnomorskiego znajduje się wiele osób z państw Afryki Zachodniej, Wschodniej, a także Rogu Afryki: zwłaszcza Mali, Nigerii, Nigru, Erytrei, Somalii. Na północnoafrykańskie wybrzeże Morza Śródziemnego docierają oni trzema trasami, które są dobrze rozpoznane i kontrolowane przez grupy przemytnicze. Większość migrantów korzysta na trasie z miast służących za centra, w których starają się uzyskać zasoby konieczne dla dalszej podróży i zapewnić sobie usługi przemytników (Collyer, 2004). Warto dodać, że podróż z państw Afryki Subsaharyjskiej do Europy, wliczając w to długookresowe postoje, może zabrać nawet kilka lat. Wśród tras afrykańskich, które prowadzą na wybrzeża libijskie i egipskie możemy wyróżnić (UNODC, 2010, s. 68):

1) trasę zachodnioafrykańską (Sierra Leone lub Liberia, Gwinea, Mali, Algieria, Libia) z centrami w Gao (Mali), Tamanrasset (Algieria);

2) trasę środkowoafrykańską (Nigeria, Niger, Libia) z centrum w Agadezie (Niger);

3) trasę wschodnioafrykańską (Etiopia lub Erytrea, Sudan, Egipt lub Libia) z takimi centrami jak: Addis Abeba (Etiopia), Al-Kadarif (Sudan), Kassala (Sudan), Selima (Sudan), Al-Dżauf/Al-Kufra (Libia).

Szczególnie ważnymi miejscami dla sieci przemytniczych i migrantów na trasach afrykańskich są wspomniane centra, takie jak Gao (trasa zachodnioafrykańska) czy Agadez (trasa środkowoafrykańska). Stamtąd migranci przewożeni są do Libii względnie do Algierii (Tamanrasset), skąd część z nich kieruje się na północ. Po przekroczeniu granicy algiersko-marokańskiej docierają do miasta Wadżda. Z Maroka migranci starają się przedostać na terytorium południowej Hiszpanii. Na trasie wschodnioafrykańskiej migranci gromadzą się w Addis Abebie. Liczni wśród nich Somalijczycy docierają tam od wschodu przez przejście graniczne znajdujące się w pobliżu Hargejsy (Somalia) lub położone na południu przejście graniczne w Dolo (Etiopia). Z Addis Abeby - Somalijczycy i Etiopczycy - transportowani są przez Sudan, z przystankami w takich centrach, jak Al-Kadarif, Selima i Al-Dżauf/Al-Kufra. Niezwykle ważnym centrum migracyjnym jest Kassala, skąd migranci jadą do Egiptu lub Libii.

Wspominane trasy kontrolowane są przez dobrze zorganizowane sieci przemytnicze składające się z wysoce wyspecjalizowanych, wyposażonych w odpowiednią wiedzę i kontakty osób. Nierzadko prowadzą one legalną działalność (np. agencje podróży) lub korzystają z usług mniejszych grup przestępczych, specjalistów w zakresie fałszowania dokumentów, milicji, drobnych kryminalistów a nawet zwykłych obywateli, takich jak taksówkarze, kierowcy ciężarówek, bankierzy. Członkowie transnarodowych grup przemytniczych w zależności od roli pełnionej w organizacji operują kilkoma językami obcymi. Przewagę nad migrantami budują w oparciu o niewiedzę tych ostatnich, prawdy obiegowe, niepotwierdzone wiadomości, obawy, a także tworzenie iluzji zaufania. Starają się w jak największym stopniu uzależnić migrantów od 
siebie, przy okazji windując cenę za świadczone usługi. Podstawową techniką wykorzystywaną na etapie rekrutacji migrantów jest wytwarzanie poczucia braku czasu, napięcia, nagłości wymagającej szybkiego podjęcia decyzji przez potencjalnego migranta. Przekonując go, aby ,zdecydował się bo inaczej oni wybudują mur i nikt nie przedostanie się" przemytnicy kreślą obraz osób, którym można zaufać. Wbrew stereotypowemu obrazowi powielanemu przez media, migranci zazwyczaj pochodzą z miast i są relatywnie dobrze wykształceni. W części opracowań wskazuje się, że większość Afrykanów zmierzających do Libii, ma średnie wykształcenie (Escoffer, 2009, rozdział 4). Wielu z nich przed podjęciem decyzji o migracji wykonuje prace (często dobrze płatną jak na warunki lokalne). Pomimo, że wśród migrantów z Afryki Subsaharyjskiej oraz Północnej przeważają mężczyźni, zwykle w wieku 20-30 lat, liczba kobiet wciąż wzrasta. ONZ jako przyczynę tego trendu wskazuje zjawisko dołączania żon do wcześniej migrujących mężów (UN, 2008, s. 43). Z przemieszczaniem się kobiet związane jest szereg niepokojących zjawisk. Za jedno z nich należy uznać „eksport” młodych kobiet i dziewcząt z Afryki do Europy, gdzie są wykorzystywane przez organizacje przestępcze i zmuszane do prostytucji. Szacuje się, że co roku ok. 5,7 tys. kobiet, zwłaszcza z Nigerii, trafia do Europy (głównie do Włoch), gdzie są zmuszane do świadczenia usług seksualnych.

Aktywność przemytników w poszukiwaniu potencjalnych klientów nie dziwi, biorąc pod uwagę rosnącą konkurencję, związany z tym spadek cen usług i konieczność wyrównywania strat poprzez zwiększenie liczby transportowanych migrantów. Wśród liczących się grup przemytniczych walczących o dostęp do wybrzeży Afryki Północnej znajdują się nomadyczne klany Tuaregów i Tebu. Korzystając z kryzysu politycznego w Libii po upadku Kadafiego w 2011 r., stały się ważnymi ogniwami wielopoziomowego i wysoce zorganizowanego systemu przemytniczego. W szczególności klan Tebu kontrolujący obszary południowej Libii, Czadu i północnego Nigru, specjalizuje się w transporcie ludzi do Al-Kufry i na zachód do Sabhy, a także w kierunku śródziemnomorskich miast takich jak Bengazi, Trypolis i Zuwara. Po uszczelnieniu kontroli granicznych przez Egipt kierunek libijski wydaje się jeszcze bardziej atrakcyjny dla przemytników. Korzystają z niego w głównej mierze migranci z Afryki Subsaharyjskiej, docierający do Europy drogą morską z Libii (tab. 1).

Tabela 1

Państwa północnoafrykańskie* $\mathrm{z}$ których migranci wyruszyli na wybrzeże Włoch oraz ich liczba w latach 2013-2014

\begin{tabular}{||c|c|c|c|c||}
\hline \hline & Libia & Egipt & Algieria & Tunezja \\
\hline 2013 & 27233 & 9190 & 24 & 871 \\
\hline 2014 & 141293 & 15413 & 155 & 1215 \\
\hline
\end{tabular}

*Dane nie obejmują Maroka.

Źródło: Szacunki włoskiej straży przybrzeżnej.

Z powyższymi danymi korelują informacje przekazywane przez agencję Frontex. Wskazuje się w nich, że w 2014 roku wszystkimi szlakami przybyło do Europy ponad 276 tys. migrantów, z czego ponad 170 tysięcy - centralnym szlakiem śródziemnomorskim (głównie z Libii i Egiptu) prowadzącym do Włoch i na Maltę. 
Liczba nielegalnych migrantów docierających do Europy w latach 2013-2014 centralnym i wschodnim szlakiem śródziemnomorskim

\begin{tabular}{||l|c|c|}
\hline \hline & $\mathbf{2 0 1 3}$ & $\mathbf{2 0 1 4}$ \\
& (styczeń-grudzień) & (styczeń-grudzień) \\
\hline Centralny szlak śródziemnomorski (Włochy, Malta) & 45298 & 170816 \\
\hline Wschodni szlak śródziemnomorski (Grecja, Cypr, Włochy) & 23299 & 50561 \\
\hline Razem, wliczając pozostałe szlaki & 107964 & 276113 \\
\hline
\end{tabular}

Źródło: Questions and Answers: Smuggling of Migrants in Europe and the EU response, European Commission, Brussels, 13 January 2015.

Korzyści z procederu przemytu czerpią także organizacje terrorystyczne. Al-Kaida, która jeszcze przed 2011 r. zajmowała się przemytem ludzi, narkotyków i broni, działając głównie na pustynnych obszarach południowej Libii, współpracuje z Tuaregami i Tebu. Inne grupy terrorystyczne, takie jak Al-Murabitun dowodzona przez Algierczyka Muchtara Bilmuchtara, korzystając z powiązań przemytniczych działają nie tylko w Libii, ale też w państwach takich jak Mali, Niger, Czad i Algieria (Mindal, Sasnal, 2016). Centralny szlak śródziemnomorski w znaczącym stopniu jest także kontrolowany przez grupy przemytnicze działające na trasie wschodnioafrykańskiej. Duże zyski z przemytu uchodźców i osób poszukujących azylu przed opresyjnym reżimem w Erytrei i konfliktem w Somalii uzyskują liczne grupy przestępcze zajmujące się rekrutowaniem i przemytem migrantów z Rogu Afryki. Według badań wykonanych przez Regional Mixed Migration Secretariat, w samej tylko Addis Abebie w 2013 roku znajdowało się 1 tys. nielegalnych i niezarejestrowanych ,agentów/brokerów” oraz 406 zarejestrowanych agencji pracy (RMMS, 2014, s. 17-30).

Większość migrantów z trzech wspomnianych tras afrykańskich trafia do Libii, w której według szacunków Międzynarodowej Organizacji ds. Migracji (International Organization for Migration - IMO), w listopadzie 2011 r. znalazło schronienie ok. 800 tysięcy osób (IOM, 2011). Obok Syryjczyków (którzy w kolejnych latach coraz częściej korzystali ze szlaku egejskiego) wśród migrantów znajdują się mieszkańcy poszczególnych państw afrykańskich (Burkina Faso, Kongo, Wybrzeże Kości Słoniowej, Erytrea, Gambia, Ghana, Gwinea, Liberia, Mali, Niger, Nigeria, Senegal, Somalia, Sudan) oraz azjatyckich (Pakistan, Bangladesz). Działające tam sieci przemytnicze charakteryzowane są jako luźno powiązane ze sobą grupy osób złączone więzami finansowymi. Na poziomie lokalnym, każda z nich na określonym odcinku szlaku migracyjnego dokonuje transportu migrantów przez terytorium libijskie i Morze Śródziemne na Maltę lub włoskie wyspy Lampedusa, Pantelleria lub Sycylia (De Hass, 2007, s. 18). Pomiędzy grupami przemytniczymi trudno mówić o znaczącej koordynacji działań, choć zauważalne są nieformalne kontakty między afrykańskimi operatorami tras przemytniczych z Czadu i Sudanu a libijskimi przemytnikami z takich centrów jak Al-Kufra czy Sabha (Hamood, 2006).

Dla końcowego etapu przemytu drogą morską szczególne znaczenie ma Sabha. Miasto znajdujące się na terytorium środkowo-zachodniej Libii jest głównym ośrodkiem kierowania migrantów to Trypolisu i innych miast libijskiego wybrzeża (De Hass, 2007, s. 18). Z Sabhy migrantów transportuje się tam ciężarówkami. Alternatywnie ciężarówki wyruszają z Al-Kufry do Adżdabiji (pomniejsze centrum), a następnie dro- 
gą nabrzeżną do Trypolisu. O natężeniu ruchu świadczy fakt, że z głównych centrów przemytu każdego tygodnia wyrusza ok. 100 ciężarówek, mieszczących od 25 do 35 osób. Rekruterzy dołączają ciężarówkę do konwoju dopiero po zebraniu wystarczającej liczby migrantów. Do tego czasu ci ostatni są przetrzymywani w obozowiskach znajdujących się na obrzeżach miast przesiadkowych. Co istotne, transport migrantów drogą morską do Europy kontrolują Libijczycy, podczas gdy grupy Tebu działają na południu Libii.

Grupy przemytnicze charakteryzuje hierarchiczna struktura. Na jej czele stoi kilku bossów, którzy pośredniczą w kontaktach na najwyższym poziomie z innymi sieciami przemytniczymi, przedstawicielami lokalnej administracji, władz, policji. Sami migranci $\mathrm{w}$ wywiadach potwierdzają, że libijska i egipska administracja zajmująca się zarządzaniem infrastrukturą portową, ochroną wybrzeża itd. utrzymuje rozległe kontakty z przedstawicielami grup przemytniczych oraz tzw. łącznikami mającymi dostęp do wysokich rangą, decyzyjnych, osób w wojsku. Grupy te dzielą się zyskami z przemytu. Pytany o te kwestie migrant z Erytrei stwierdził: „w przypadku nieporozumień osoby decyzyjne zajmują łodzie z migrantami, a tych ostatnich umieszczają w areszcie" (RMMS, 2014, s. 47). Niższą pozycję w strukturze organizacyjnej grup przemytniczych zajmują tzw. koordynatorzy. Dysponują oni wyspecjalizowaną wiedzą, lokalnymi powiązaniami, często znają więcej niż jeden język obcy. Prowadzą też nierzadko legalnie działające interesy (np. biura podróży). Do ich obowiązków należy ochrona ładunku. Niżej w strukturze znajdują się pośrednicy, którzy odpowiadają za pobór pieniędzy od rekruterów (brokerów), pośredniczą w kontaktach rekruterów z rybakami, dysponującymi kutrami przewożącymi migrantów, załatwiają pozostałe kwestie związane z transportem. Rekruterzy/brokerzy znajdują się na dole łańcucha ekonomii krymigracyjnej. Zajmują się pozyskiwaniem potencjalnych migrantów i organizowaniem pierwszego etapu podróży. Poniżej przedstawiono strukturę modelu biznesowego organizacji przemytniczej, charakterystycznego dla Libii i Egiptu (rys. 1) a także symulację zysków/kosztów związanych z przemytem migrantów centralnym szlakiem śródziemnomorskim.

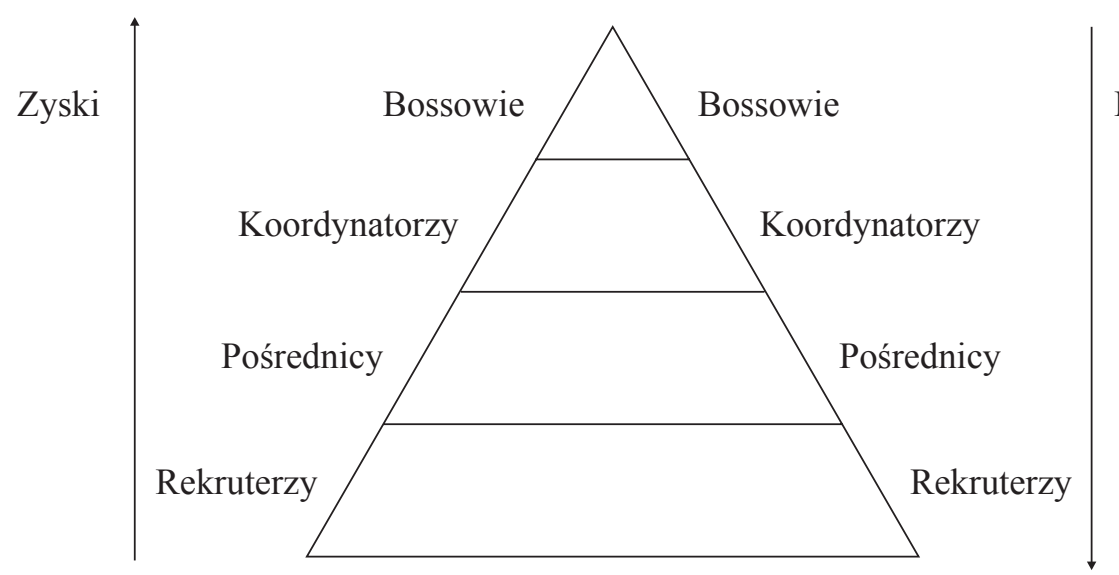

Hierarchia

Rys. 1. Struktura modelu biznesowego organizacji przemytniczej

Źródło: Opracowanie własne na podstawie dostępnych wywiadów z migrantami/przemytnikami. 
Struktura zysków/kosztów przemytu migrantów centralnym szlakiem śródziemnomorskim

\begin{tabular}{|c|c|c|}
\hline Zyski & \multicolumn{2}{|c|}{2 tys. USD za migranta x 250 osób $=500$ tys. USD } \\
\hline Bossowie & $60 \%$ & 300 tys. USD \\
\hline Przemytnicy & $25 \%$ & 125 tys. USD \\
\hline Pośrednicy & $10 \%$ & 50 tys. USD \\
\hline Rekruterzy & 5\% (średnio po 100 USD za migranta) & 25 tys. USD \\
\hline Koszty & \multicolumn{2}{|c|}{$\begin{array}{l}\text { Dotyczące zarówno transportu lądowego migrantów do Libii jak również } \\
\text { transportu morskiego z Libii do Włoch/na Maltę }\end{array}$} \\
\hline Łapówki & $\begin{array}{l}\text { Checkpointy (posterunki w których kontroluje się } \\
\text { ciężarówki) }\end{array}$ & $\begin{array}{l}\text { min. } 100 \text { USD na każdy } \\
\text { checkpoint }\end{array}$ \\
\hline Opłaty rezydencyjne & $\begin{array}{l}\text { Wynajęcie kryjówki (safe house), gdzie trzyma się } \\
\text { migrantów pod nadzorem w oczekiwaniu na trans- } \\
\text { port }\end{array}$ & 5 tys. USD miesięcznie \\
\hline Opłaty przewozowe & $\begin{array}{l}\text { 1. Koszt łodzi mogącej przyjąć ok. } 250 \text { migran- } \\
\text { tów. } \\
\text { 2. Koszt pontonu z pomocą którego dowozi się do } \\
\text { łodzi grupy liczące ok. } 20 \text { migrantów. } \\
\text { 3. Wynagrodzenie kapitana łodzi wypływającej } \\
\text { z migrantami na wody międzynarodowe }\end{array}$ & $\begin{array}{l}80 \text { tys. USD } \\
4 \text { tys. USD } \\
\text { 5-7 tys. USD }\end{array}$ \\
\hline $\begin{array}{l}\text { Opłaty telekomuni- } \\
\text { kacyjne }\end{array}$ & $\begin{array}{l}\text { Koszt zakupu telefonu satelitarnego z którego mi- } \\
\text { granci znajdujący się na wodach międzynarodo- } \\
\text { wych mogą wzywać pomoc }\end{array}$ & ok. 800 USD \\
\hline
\end{tabular}

Źródło: Opracowanie własne na podstawie dostępnych wywiadów z migrantami/przemytnikami.

Przedstawiona w tabeli 3 kalkulacja, opiera się na założeniu, że migrant za transport drogą morską z wybrzeży libijskich do Włoch płaci 2 tys. USD. W rzeczywistości jest to górna granica opłat, które w miesiącach letnich (tzw. peak season) wahają się od 1,5 do 2 tys. USD. Zwykle jednak za transport przez Morze Śródziemne przemytnicy pobierają od 800 do 1 tys. USD. Warto też zaznaczyć, że koszty po stronie migrantów rosną wraz z opłatami związanymi z dojazdem do miejsca wypłynięcia w morze. Z wywiadów z migrantami przeprowadzonych przez Regional Mixed Migration Secretariat wynika, że dodatkowe opłaty obejmują (RMMS, 2014, s. 49):

1) 254 USD za dojazd z Abu Salim (dzielnica Trypolisu) do Garabulli, portu rybackiego w zachodniej części miasta, uznawanego za główny ośrodek, z którego wyruszają w morze pontony/małe łodzie rybackie z migrantami;

2) 489 USD, względnie 600 libijskich dinarów (w przypadku jeśli migranci nie dysponują twardą walutą) za dojazd z Sabhy do Trypolisu;

3) 600 USD za dojazd z Bengazi do Trypolisu.

Regułą jest jednak brak sztywnych reguł dotyczący wysokości opłat. Na tę cechę przestrzeni rynkowej TEK wskazali m.in. Reitano i Tinti (2015). Zauważyli, że na centralnym szlaku śródziemnomorskim Sudańczycy ponoszą znacznie wyższe koszty od Syryjczyków. Przyczyną tychże różnic jest słabiej rozwinięta sieć sudańskich grup przemytniczych, co niewątpliwie ma znaczenie w przypadku przemytu migrantów z Egiptu, gdzie lokalna gospodarka krymigracyjna odzwierciedla podziały narodowościowe. Reitano i Tinti zaobserwowali ponadto, że dodatkowym czynnikiem, czy też kartą przetargową, wpływającą na niższe koszty ponoszone przez Syryjczyków 
jest możliwość skorzystania przez nich ze szlaku egejskiego, zwłaszcza że mogą oni podróżować do Turcji bez konieczności uzyskiwania wiz. W dużo gorszej sytuacji od Syryjczyków oraz Sudańczyków znajdują się Somalijczycy i Erytrejczycy. Wielu z nich po opuszczeniu regionalnych obozów dla uchodźców nie dysponuje zasobami pozwalającymi im na negocjowanie z przemytnikami. Zarówno w Egipcie jak również w Libii, gdzie system prawny uległ całkowitej dekonstrukcji, stają się oni łatwym celem dla handlarzy ludźmi, milicji i lokalnych grup przestępczych (Reitano, Tinti, 2015, s. 15-16).

Dynamiczny rozwój transnarodowej ekonomii krymigracyjnej przynosi grupom przemytniczym rosnące zyski, i to mimo narastania konkurencji na centralnym szlaku śródziemnomorskim. Szacuje się że wartość handlowa przemytu migrantów drogą morską z Libii do Włoch przekracza rocznie 100 mln USD (van Reisen, Estefanos, Eijken, 2013, s. 120). Tym samym proceder ten staje się jednym z filarów transnarodowej przestępczości zorganizowanej.

\section{Reakcja Unii Europejskiej na przemyt migrantów centralnym szlakiem śródziemnomorskim}

Unia Europejska w obliczu nasilania się aktywności transnarodowych grup przemytu migrantów operujących na centralnym szlaku śródziemnomorskim podjęła działania, które można przyporządkować do trzech grup.

W pierwszej z nich podejmuje się działania operacyjne. Wśród nich priorytetowe znaczenie ma wspólna operacja „Tryton” mająca wesprzeć Włochów w zmaganiu się $\mathrm{z}$ falą migracyjną ${ }^{9}$. Wpisuje się ona $\mathrm{w}$ europejski program $\mathrm{w}$ zakresie migracji, $\mathrm{w}$ tym zwłaszcza realizację takich celów jak: 1) ograniczenie czynników sprzyjających nielegalnej migracji m.in. przez przyjęcie nowej strategii przewidującej środki przekształcające działalność przemytników ludzi; 2) zarządzanie granicami - ratowanie ludzkiego życia i zabezpieczanie granic zewnętrznych, zwłaszcza poprzez umocnienie roli i możliwości Frontexu oraz skupianiu określonych funkcji straży przybrzeżnej na poziomie UE; 3) dążenie do zapewnienia pełnego i spójnego wdrożenia wspólnego europejskiego systemu azylowego; 4) zaproponowanie nowych rozwiązań w zakresie europejskiej polityki dotyczącej legalnej migracji (KE, 2015a, s. 8-20). Cztery filary europejskiej polityki migracyjnej wypracowano jako odpowiedź na tragedię w basenie Morza Śródziemnego, do której doszło 3 października 2013 r. u wybrzeża Lampedusy. Zatonięcie łodzi, która wyruszyła z libijskiego wybrzeża w okolicach Misraty spowodowało śmierć 366 migrantów głównie z Somalii i Erytrei (Bielecki, 2013). Operację „Tryton”, uruchomioną 1 listopada 2014 roku w centralnym obszarze Morza Śródziemnego, uznano za część europejskiego programu w zakresie migracji, a także jako wsparcie dla militarno-humanitarnej operacji Mare Nostrum, realizowanej przez Włochy w latach 2013-2014 ${ }^{10}$. Do koordynacji działań upoważniono agencję Frontex. Na

${ }^{9}$ W ramach bliźniaczej operacji Posejdon, prowadzonej od 2013 roku, patrolowane są wody Morza Egejskiego.

${ }^{10}$ Warto zauważyć, że operacja ta, podjęta przez Włochów po tragedii z 3 października $2013 \mathrm{r}$. pozwoliła na uratowanie ponad 100 tys. migrantów (do października 2014 r.). Wiele państw UE 
współpracę w ramach „Trytona” zgodę wyraziło 21 państw członkowskich UE. Z miesięcznego budżetu ustalonego początkowo na 2,9 mln euro i zwiększonego w połowie 2015 roku, sfinansowano zasoby ludzkie (65 osób), a także zasoby techniczne: dwa stałopłaty, jeden helikopter, dwa dalekomorskie statki patrolowe, sześć statków patrolu przybrzeżnego, jedną przybrzeżną łódź patrolową, pięć zespołów informacyjnych/ dochodzeniowych (KE, 2015b).

Druga grupa działań podejmowanych przez UE mających na celu przeciwdziałanie nieregularnej migracji na centralnym szlaku śródziemnomorskim, walkę z sieciami przemytniczymi i ratowanie życia migrantów ma wymiar finansowy. Główne cele zasygnalizowano w Europejskim programie w zakresie migracji, którego założenia Komisja Europejska przedstawiła w maju 2015 roku (KE, 2015a). W odniesieniu do sytuacji nadzwyczajnych zasygnalizowano tam potrzebę potrojenia finansowania operacji „Tryton” i „Posejdon”, a także wsparcie ewentualnej misji WPBIO w zakresie walki z przemytem migrantów (KE, 2015a, s. 8). Zapisy te zostały potwierdzone w projekcie budżetu UE na rok 2016. Zwrócono w nim szczególną uwagę na wyzwania związane z migracją. Nie tylko zaproponowano przeznaczenie dodatkowych środków na operacje „Tryton” i „Posejdon”, ale także zwiększenie pomocy w sytuacjach nadzwyczajnych dla państw członkowskich położonych na granicach zewnętrznych Unii ${ }^{11}$, finansowanie ogólnoeuropejskiego systemu przesiedleń oraz wzmocnienie agencji takich jak Frontex i Europejski Urząd Wsparcia w dziedzinie Azylu (EASO). W budżecie UE na 2016 r. zarezerwowano 833 mln na Fundusz Azylu, Migracji i Integracji (AMIF) oraz Fundusz Bezpieczeństwa Wewnętrznego (ISF). Warto podkreślić, iż są to dwa główne źródła finansowania działań w ramach unijnej polityki migracji i bezpieczeństwa (KE, 2015c).

Ostatnia grupa działań podejmowanych przez UE ma na celu stworzenie ram prawnych w dziedzinie zwalczania przemytu migrantów. Podstawowe znacznie ma tutaj implementacja tzw. „facilitators package”, obejmującego dwa akty prawne przyjęte przez Radę UE. Pierwszym z nich jest Dyrektywa Rady 2002/90/WE z dnia 28 listopada 2002 r. definiująca ułatwianie nielegalnego wjazdu, tranzytu i pobytu (Rada, 2002a). Drugi z aktów normatywnych to Decyzja ramowa Rady z dnia 28 listopada 2002 r. w sprawie wzmocnienia systemu karnego w celu zapobiegania ułatwianiu nielegalnego wjazdu, tranzytu i pobytu (Rada, 2002b). Należy zauważyć, że skuteczność obu dyrektyw jest ograniczona. Obecnie trwa ocena stanu ich implementacji w świetle

odmawiało pomocy zarzucając Włochom, że operacja stała się „magnesem” przyciagającym imigrantów do Europy.

${ }^{11}$ Największym beneficjentem funduszy przeznaczonych na kwestie związane z migracją (Europejskiego Funduszu na rzecz Uchodźców, Europejskiego Funduszu na rzecz Integracji Obywateli Państw Trzecich, Europejskiego Funduszu Powrotów Imigrantów i Funduszu Granic Zewnętrznych) są Włochy. W latach 2007-2013 państwo to otrzymało z tytułu czterech wyżej wskazanych funduszy od UE kwotę podstawową w wysokości 478,7 mln euro. Także w perspektywie 2014-2020. Włochy są największym beneficjentem unijnej pomocy w dziedzinie migracji. Znaczącą pomoc finansową UE kieruje także do Malty, jako drugiego obok Włoch, celu relokacyjnego migrantów na centralnym szlaku śródziemnomorskim. 4 lutego 2015 r. ogłoszono, że ze środków Funduszu Bezpieczeństwa Wewnętrznego, maltańskim siłom zbrojnym przyznane zostało ponad 12 milionów euro. Środków tych udzielono z przeznaczeniem na ochronę granicy morskiej przed napływem nielegalnych migrantów. 
możliwości wzmocnienia istniejących sankcji za przestępstwa popełniane w związku z przemytem.

\section{Zakończenie}

Rozważania podjęte w niniejszym artykule są jednym z głosów w debacie na temat kryzysu migracyjnego w Europie. Wśród wielu przyczyn wzbierania fali nieregularnej migracji na pierwszy plan wysuwa się rozkwit ekonomii krymigracyjnej. Za jej stronę podażową odpowiadają liczne i dobrze zorganizowane sieci przemytnicze, współpracujące z lokalną administracją, a nierzadko też z organizacjami terrorystycznymi. Popyt na usługi przemytników zgłaszają zaś sami migranci, skłonni słono zapłacić za szansę poprawy warunków bytowych i ucieczki od zawieruchy wojennej i politycznej w rodzimych państwach. Działają z zamiarem wynikowym, tj. przewidując (choć w różnym stopniu) niebezpieczeństwa związane z transportem do miejsca docelowego - godzą się na to. Tym samym przyczyniają się do napędzania procederu przemytniczego. Nierzadko jednak z klientów przemytników stają się ofiarami handlu ludźmi. Dotyczy to zwłaszcza kobiet, z których tysiące są wykorzystywane po dotarciu do Europy przez grupy przestępcze. Tym samym szansa na poprawę warunków życia zamienia się w piekło codziennej egzystencji, a migrant staje się uprzedmiotowiony i zamieniony w towar, którym obraca się w kryminalnej przestrzeni rynkowej.

Przemyt migrantów, generując dochód rzędu ponad 100 mln USD rocznie, stanowi liczącą się gałąź działalności transnarodowej przestępczości zorganizowanej. Napędzany przez bezgraniczną chciwość przemytników posuwających się do przemocy fizycznej i psychicznej w celu pozyskania „klientów”, staje się procederem, w który zaangażowane są także osoby prowadzące legalną działalność gospodarczą - właściciele biur podróży, taksówkarze, kierowcy, właściciele pensjonatów, sklepów z zaopatrzeniem dla migrantów. Centralny szlak śródziemnomorski, to końcowy etapu relokacji do Europy, poprzedzony nierzadko kilkuletnią podróżą z państw Afryki Subsaharyjskiej oraz Azji. Należy dodać, że jest to podróż skrajnie niebezpieczna, obfitująca w wiele zagrożeń dla migrantów. Szeroka skala procederu przemytu migrantów i tragiczne skutki z tym związane, a także dynamiczny rozwój rynku opanowanego przez przestępczość zorganizowaną wywołują potrzebę skutecznej reakcji Unii Europejskiej, jako obszaru znajdującego się na celowniku przemytników. Pomimo szeregu działań operacyjnych, finansowych i prawnych, podejmowanych od 2013 r., ich wyniki są suboptymalne. Krytycy polityki migracyjnej Unii Europejskiej nie bez racji zarzucają jej brak zintegrowanego podejścia do problematyki zwalczania przemytu migrantów. Co prawda w przypadku pomyślnej realizacji założeń czterech filarów europejskiego programu w zakresie migracji ocena ta może ulec zmianie, jednakże na obecnym etapie trudno mówić o sukcesach. Niewątpliwie warte podkreślenia jest sukcesywne zwiększanie przez Unię Europejską środków finansowych przeznaczonych na radzenie sobie z kryzysem migracyjnym, np. poprzez dofinansowanie takich operacji jak „Tryton” i „Posejdon”, a także zwiększenie pomocy w sytuacjach nadzwyczajnych dla państw członkowskich położonych na granicach zewnętrznych Unii. Jednakże i tutaj 
krytycy UE zgłaszają uzasadnione zastrzeżenia. Podkreśla się bowiem, że działania głównej agencji UE odpowiadającej za problematykę migracji - Frontexu - często skupiają się bardziej na wzmacnianiu mechanizmów ochronnych, niż na ratowaniu ludzkiego życia. Na tym tle pojawia się wątpliwość - co powinno być priorytetem dla Unii w rozwiązywaniu problemu nieregularnych migracji na centralnym szlaku śródziemnomorskim: koordynowanie współpracy w zakresie wzmacniania ochrony granic UE czy ratowanie ludzkiego życia? Innym zagadnieniem, które UE musi rozstrzygnąć jest podejmowanie średnio- i długofalowych przedsięwzięć mających na celu zwalczanie przemytu migrantów. Do kluczowych można zaliczyć: 1) zacieśnianie współpracy organów ścigania państw członkowskich oraz agencji UE (np. Europolu, Frontexu) w wykrywaniu zorganizowanych grup przestępczych trudniących się organizacją przemytu; 2) wzmocnienie działań wywiadowczych służących wykrywaniu przypadków ułatwiania nieregularnej migracji (tzw. Focal Point Checkpoint); 3) rozwój mechanizmów sprawozdawczych odnośnie do sposobu działania przemytników oraz tras przemytu, a także 4) wzmocnienie instytucjonalne i finansowe Europejskiego Urzędu Wsparcia w dziedzinie Azylu. Nade wszystko wydaje się, że UE powinna zmienić swoją filozofię działania w odniesieniu do transnarodowej ekonomii krymigracyjnej - silnie usieciowionej gałęzi gospodarki przestępczej mającej wciąż duży potencjał wzrostu i ekspansji. Zachodzi jednak pytanie, czy Europa, której wielu „obywateli” utożsamia migrantów z terrorystami, gdzie rośnie popularność partii skrajnie prawicowych, w której wyraźnie odczuwa się brak charyzmatycznego przywództwa politycznego, zachodzenie partykularyzmów i tendencji antysolidarystycznych, będzie takiemu celowi w stanie sprostać.

\section{Bibliografia}

Aiyar S., Barkbu B., Batini N., Berger H., Detragiache E., Dizioli A., Ebeke Ch., Huidan L., Linda L., Sosa S., Spilimbergo A., Topalova P. (2009), The Refugee Surge in Europe: Economic Challenges, IMF.

Bielecki T. (2013), Tragedia u wybrzeży Lampedusy: śmierć w drodze ku lepszemu życiu, „Gazeta Wyborcza", 4.10.2013, wyd. elektroniczne, http://wyborcza.pl/1,76842,14718428, Tragedia_u_wybrzezy_Lampedusy_smierc_w_drodze_ku.html, 20.07.2016.

Bilecen B. (2009), Human Smuggling Networks Operating Between Middle East and the European Union: Evidence from Iranian, Iraqi and Afghani Migrants in the Netherlands, Bielefeld: COMCAD.

Buczek D. (2015), Unia Europejska wobec zjawiska przemytu migrantów, Raport Komisji Europejskiej, „Questions and Answers: Smuggling of Migrants in Europe and the EU Response”, „Newsletter EFPI”, nr 1 (21).

Clandestino Project (2009), Clandestino Project Final Report, Athens: Hellenic Foundation for European and Foreign Policy, http://clandestino.eliamep.gr/wp-content/uploads/2010/03/clandestino-final-report_november-2009.pdf.

Collyer, M. (2004), Undocumented Sub-saharan African Migrants in Morocco, Working Paper. Falmer: Sussex Centre for Migration Research, University of Sussex.

Daniel S. (2008), Les routes clandestines: L'Afrique des immigrés et des passeurs, Hachette, Paris.

Haas de H. (2007), The myth of invasion: Irregular migration from West Africa to the Maghreb and the European Union, Oxford: International Migration Institute. 
Del Carpio X., Wagner M. (2015), The Impact of Syrian Refugees on the Turkish LaborMarket, Working Paper WPS7402, World Bank Group, Washington.

EC (2009), European Commission, Standard Eurobarometer 71: Public Opinion in the European Union, Brussels, European Commission, http://ec.europa.eu/public_opinion/archives/eb/ eb71/eb71_std_part1.pdf, 20.06.2016.

Escoffier C. (2008), Transmigrant-e-s africain-e-s au Maghreb: une question de vie ou de mort, Paris, Harmattan, chap. 4.

Fiedler R., Osiewicz P. (2015), Transformation Processes in Egipt after 2011 - The Causes, Their Course and International Response, Logos Verlag, Berlin.

Frontex (2009), The Impact of the Global Economic Crisis on Illegal Migration to the EU, Warsaw: Frontex Risk Analysis Unit, www.europarl.europa.eu/meetdocs/2009_2014/documents/libe/ dv/frontex_/frontex_en.pdf, 20.06.2016.

Gallagher A. T. (2015), Migrant Smugling, w: Routledge Handbook on Transnational Criminal Law, red. N. Boister, R. J. Currie, Routledge.

GMFUS (2011), Transatlantic Trends: Immigration 2010, German Marshall Fund of the United States Washington, DC, www.gmfus.org/trends/immigration/doc/TTI2010_English_Key.pdf, 20.06.2016.

Hamood S. (2006), African transit migration through Libya to Europe: the human cost, Cairo: The American University in Cairo.

Heckmann F. (2004), Illegal migration: what can we know and what can we explain? The case of Germany, „International Migration Review”, vol. 38, no. 3.

Horwood Ch. (2009), In Pursuit of the Southern Dream: Victims of Necessity - Assessment of the Irregular Movement of Men from East Africa and the Horn to South Africa, International Organization for Migration, Geneva.

http://data.worldbank.org/country/turkey.

IOM (2011), Migration Crisis from Libya - IOM Middle East North Africa, Geneva.

KE (2015a), Komunikat Komisji do Parlamentu Europejskiego, Rady, Europejskiego Komitetu Ekonomiczno-Społecznego i Komitetu Regionów. Europejski program w zakresie migracji, COM (2015) 240 final, Bruksela, 13 maja.

KE (2015b), Komisja Europejska wspiera Włochy w radzeniu sobie z napływem imigrantów na Lampedusie, Bruksela, 19 luty.

KE (2015c), Komisja przedstawia projekt budżetu UE na rok 2016: zwraca się w nim szczególnq uwage na tworzenie miejsc pracy, wzrost gospodarczy, migrację oraz działania na skale światowa, Bruksela, 27 maj.

IOM (2011), Operations. Daily Statistical Report, 27 November 2011, Cairo: International Organization for Migration.

Lawton R. (1968), Population changes in England and Wales in the later nineteenth century: an analysis of trends by registration district, „Transactions of the Institute of British Geographers", vol. 44.

Lee E. S. (1966), A Theory of Migration, „Demography”, vol. 3, issue 1.

Minda A., Sasnal P. (2016), Kryzys w Libii a wzrost dżihadyzmu i migracji, „Biuletyn” PISM, nr 21 (1371), 10 marca.

Neske M. (2006), Human smuggling to and through Germany, „International Migration”, vol. 44, no. 4.

Okólski M. (2006), Costs and benefis of migration for Central European countries, „CMR Working Papers", no. 7/65.

ONZ (2015), Przemyt migrantów, Ośrodek Informacji ONZ w Warszawie, marzec, http://www.unic. un.org.pl/przestepczosc2015/39,2696. 
ONZ (2000a), Protokót przeciwko przemytowi migrantów drogq lqdowq, morska i powietrzna, uzupetniajacy Konwencję Narodów Zjednoczonych przeciwko międzynarodowej przestępczości zorganizowanej, przyjęty przez Zgromadzenie Ogólne Narodów Zjednoczonych dnia 15 listopada 2000 r., Dz. U. 2005, Nr 18, poz. 162.

ONZ (2000b), Protokół o zapobieganiu, zwalczaniu oraz karaniu za handel ludźmi, w szczególności kobietami i dziećmi, uzupetniajacy Konwencję Narodów Zjednoczonych przeciwko międzynarodowej przestępczości zorganizowanej, przyjęty przez Zgromadzenie Ogólne Narodów Zjednoczonych dnia 15 listopada 2000 r., Dz. U. 2005, Nr 18, poz. 163.

ONZ (2000c), Konwencja Narodów Zjednoczonych przeciwko międzynarodowej przestępczości zorganizowanej, przyjęta przez Zgromadzenie Ogólne Narodów Zjednoczonych dnia 15 listopada 2000 r., Dz. U. 2005, Nr 18, poz. 158.

Passas N., Nelken D. (1993), The thin line between legitimate and criminal enterprises: subsidy frauds in the European Community, „Crime Law and Social Change”, vol. 19, no. 3.

Piore M. (1979), Birds of Passage: Migrant Labor and Industrial Societies, Cambridge.

Przybylska-Maszner B. (2011), The Arab Spring, Wyd. WNPID UAM, Poznań.

Rada (2002a), Dyrektywa Rady 2002/90/WE z dnia 28 listopada 2002 r. definiujqca ułatwianie nielegalnego wjazdu, tranzytu i pobytu, Dz. U. WE L 328 z dnia 5 grudnia 2002.

Rada (2002b), Decyzja ramowa Rady z dnia 28 listopada 2002 r. w sprawie wzmocnienia systemu karnego w celu zapobiegania ułatwianiu nielegalnego wjazdu, tranzytu i pobytu, Dz. U. WE L 328 z dnia 5 grudnia 2002.

Reisen van M., Estefanos M., Rijken C. (2012), Human Trafficking in the Sinai: Refugees between Life and Death, Brussels, Tilburg University/EEPA.

Reitano T., Tinti P. (2015), Survive and advance The economics of smuggling refugees and migrants into Europe, Institute for Security Studies, ISS Paper ISS 289, November.

Rewizorski M. (2012), The Arab Awakening and Its Political Economy, „Polish Political Science Yearbook", nr XLI.

RMMS (2014), Going west: Contemporary mixed migration trends from the Horn of Africa to Libya and Europe, Geneva, International Organization for Migration.

Rumford C. (2003), European Civil Society or Transnational Social Space? Conception of Society in Discourses of EU Citizenship, Governance and the Democratic Deficit: An Emerging Agen$d a$, ,European Journal of Social Theory”, $\mathrm{nr} 1$.

Salt J., Stein J. (1997), Migration as a business: the case of trafficking, „International Migration”, vol. 35 , no. 4.

Salt J. (2000), Trafficking and human smuggling: a European perspective, „International Migration”, vol. 38, no. 3, Special Issue no. 1.

Stark O., Bloom D. E. (1985), The new economics of labor migration, „American Economic Review", vol. 75 , no. 2.

Staring R. (2004), Facilitating the Arrival of Illegal Immigrants in the Netherlands: Irregular Chain Migration versus Smuggling Chains, ,Journal of International Migration and Integration”, Special Issue 1, vol. 5, issue 3.

Swaminathan M. (1991), Understanding the „Informal sector”: a Survay, World Institute for Development Economics Research of the U.N. University.

Tobler W. (1995), Migration: Ravenstein, Thorntwaite, and Beyond, „Urban Geography”, vol. 16, no. 4.

UN (1997), Letter dated 16 September, 1997 from the Permanent Representative of Austria to the UnitedNations addressed to the Secretary-General, UN Doc. A/52/357, 17 September.

UNODC (2010), The Globalization of Crime: A Transnational Organized Crime Threat Assessment, Vienna,www.unodc.org/documents/data-and-analysis/tocta/TOCTA_Report_2010_low_res. pdf, 29.06.2016. 
UNODC (2011), Estimating Illicit Financial Flows Resulting from Drug Trafficking and Other Transnational Organized Crimes: Research Report, Vienna.

United Nation Treaty Collection (2016), https://treaties.un.org/Pages/ViewDetails.aspx?src=TREATY\&mtdsg_no=XVIII-12-b\&chapter=18\&lang=en, 1.07.2016.

UN (2008), United Nations Office for West Africa, Migrations irrégulières en provenance d'Afrique de l'Ouest, Etudes thématiques, September.

Webb S., Burrows J. (2009), Organised Immigration Crime: A Post-Conviction Study, Research Report No. 15, Home Office, London.

Witkowska M. (2013), Podejście transnarodowe w badaniach nad procesami politycznymi zachodzacymi w Unii Europejskiej, „Studia Politologiczne”, vol. 27.

Worbs S. (2005), Illegalität von Migranten in Deutschland, Nuremberg, Bundesamt für Migration und Flüchtlinge.

Zhang S. (2007), Smuggling and Trafficking in Human Beings: All Roads Lead to America, Westport, Connecticut, Praeger.

\section{Steszczenie}

W niniejszym artykule, autor koncentruje się na prześledzeniu relacji między „eksplozją” nieregularnych migracji do Europy a rozpowszechnianiem się i wzrostem znaczenia sieci przestępczych o transnarodowym charakterze. Punktem wyjścia jest założenie, że transnarodowa ekonomia krymigracyjna (TEK) napędzana jest przez pozaprawną aktywność aktorów prywatnych (strona podażowa) oraz przez potencjalnych migrantów, którzy zgłaszają zapotrzebowanie na tego rodzaju usługi, często nie zdając sobie w pełni sprawy z konsekwencji wejścia w relacje kontraktualne z grupami przemytników (strona popytowa). Zakłada się także, że dynamiczne funkcjonowanie transnarodowej ekonomii krymigracyjnej jest jedną z głównych przyczyn nasilania się nieregularnych migracji oraz „kryzysu migracyjnego” w Unii Europejskiej.

Słowa kluczowe: migracja, transnarodowa ekonomia krymigracyjna, przemyt, Unia Europejska

\section{The tide that has not lifted any boat. The European Union and development of the transnational economy of crimigration}

\section{Summary}

The author of this article focuses on investigating the relationship between 'explosion' of irregular migration to Europe and increasing importance of transnational criminal networks. The starting point is assumption that the transnational economy of crimigration (TEC) is driven by a non-legal activity of private actors (supply side) and potential migrants who report the demand for this kind of services, often not realizing the full extent of consequences of entry into contractual relationships with groups of smugglers (the demand side). It is also assumed that dynamics of the transnational economy of crimigration is one of the main causes of rising wave of irregular migration and the 'migration crisis' in the European Union.

Key words: migration, transnational economy of crimigration, smuggling, the European Union 
